\title{
Should Bangladesh be Integrated with Trans-Pacific Partnership? A Dynamic Panel Data Analysis
}

Md. Shaddam Hossain ( $\nabla$ rajueco09@gmail.com )

Noakhali Science and Technology University

Nobin Khor Kundu

Comilla University

Habiba Sultana

Noakhali Science and Technology University

Research

Keywords: Economic Integration, Dynamic Panel Data, Bangladesh

Posted Date: June 30th, 2021

DOl: https://doi.org/10.21203/rs.3.rs-630775/v1

License: (1) This work is licensed under a Creative Commons Attribution 4.0 International License.

Read Full License 


\title{
Should Bangladesh be integrated with Trans-Pacific Partnership? A Dynamic Panel Data Analysis
}

\author{
Md. Saddam Hossain ${ }^{\mathrm{a}}$, Nobinkhor Kundu ${ }^{\mathrm{b}}$, Habiba Sultana ${ }^{\mathrm{c}}$ \\ ${ }^{a}$ Lecturer, Department of Economics, Noakhali Science and Technology University, Noakhali- \\ 3814, Bangladesh, Email: rajueco09@gmail.com \\ ${ }^{b}$ Associate Professor, Department of Economics, Comilla University, Comilla-3506, Bangladesh. \\ ${ }^{c}$ Habiba Sultana, Research Student, Department of Economics, Noakhali Science and \\ Technology University, Noakhali-3814, Bangladesh.
}

\begin{abstract}
In this research endeavor, we have tried to assess the dynamic relationships between Bangladesh's trade balances with the Trans-Pacific Partnership (TPP) countries as well as whether Bangladesh could be benefitted if it has shown its intention to integrate with the TPP agreement. Hence, the tariff rate exporter per product is used as a proxy for economic integration variable along with conventional trade balance model. From the time span of 2005 to 2020, the simulated trade model tested for Bangladesh's merchandise trade with its TPP trading partner countries (with or without the USA). A dynamic balanced panel data analysis has used to capture the Unrestricted Error Correction Mechanism (UECM) and Generalized Method of Moments (GMM) estimator. The model has tested under two different scenarios (with or without integration), and a robustness check of the model has confirmed the validation of the specification. The study has shown that cointegration exists; stable long-run relationships from any short-run deviation and short-run dynamics has also shown convergence. Therefore, empirical results have indicated that, without integrating both scenarios the value of coefficient of proxy for economic integration variable in both cases is 0.21 and statistically significant as well as Bangladesh's trade balance is relatively better off without integration than integration with the TPP agreement. Thus, this study has suggested that Bangladesh should be maintained bilateral trade relationship instead of not joining the TPP mega-regional FTA (i.e., TPP without the USA).
\end{abstract}

Keywords: Economic Integration, Dynamic Panel Data, Bangladesh

JEL classification: F15, C33, O53 


\section{Introduction}

\subsection{Background of the Study}

Economic integration is the process of amalgamating financial plans and policies between several countries through the partial or full elimination of tariff and non-tariff restraints on trade. Economic integration's primary goal is to increase the welfare level by lowering distributors and consumers' prices and improving their economic productivity. Instead of free trade options, economic integration considered the economic theory of the second-best choice known as free trade in which there are no trade barriers. Economic integration has been treated as the 'secondbest' option for increasing productivity and welfare in global business and one of the key motives for improving the global scale of economic integration.

The regional trade agreement has increased to more than 270 , which was only 70 in 1990 . The multilateral approach to global trade negotiations has terminated after the Doha Development Round (DDR) expiry at the World Trade Organization (WTO) ministerial in Nairobi on 19 December 2015. Consequently, many countries have been moving forwards to more integrated trade across the region, such as the Trans-Pacific Partnership TPP agreement.

The TPP agreement was signed on 4 February 2016 in Auckland, New Zealand. The combined share of the world's GDP and trade of TPP countries (Australia, Brunei, Chile, Canada, Japan, Malaysia, Mexico, New Zealand, Peru, Singapore, Vietnam, and US A (e.g., until 23 January 2017) are 40 percent and 26 percent respectively. The primary purpose of this agreement is: to accelerate economic growth; create and withholding jobs; boost up productivity, competitiveness, and innovation; shrink poverty and raise the living standard of the member countries; as well as promote good governance, transparency; improved labor and environmental protections. This agreement established an Investor-State Dispute Settlement (ISDS) mechanism and envisioned lower tariff and non-tariff barriers on trade.

After finalized this regional agreement, Asia Pacific Economic Cooperation (APEC) members have shown their interest in joining TPP. Moreover, South Korea did not reveal its interest in joining TPP in 2006, but Four years later, they negotiated with US A and showed their interest in joining TPP. Similarly, many other countries and regions have shown their interest in joining TPP membership consisting of Colombia, the Philippine, and Taiwan as of 2010; Laos and Thailand as of 2012; Bangladesh, Cambodia, India, and Indonesia 2013.

Bangladesh wished to join the TPP agreement because it will not get preferential treatment of its RMG exports to the TPP member countries; thus, the RMG sector will be suffered a lot. Exporting RMG to the other countries of TPP such as Australia, Canada, Chile, Japan, and New Zealand will not trouble because Bangladesh has already enjoyed zero-duty benefits to those economies. Bangladesh might have slightly benefited from this deal because it has been the backward linkage of raw materials export such as fibers, fabrics, and yarn. But at present, a number of its rival economy like Vietnam, used to pay only 8.38 percent duty to export its RMG to the US A market, 
whereas Bangladesh pays 15.62 percent duty. In this situation, Vietnam will enjoy zero-duty benefit if TPP comes into effect, and this will be the awful news for the largest export earning sector of Bangladesh.

\subsection{Objective of the Study}

The prime objective of the present study is to determine whether Bangladesh should integrate with the TPP mega-regional FTA agreement or not.

The remaining segment of the paper as follows. Section 2 shows a review of the literature; Section 3 shows the methodology and data; Section 4 reports the validation of the model, and section 5 analyses the empirical results of the trade balance model. The last section 6 provides concluding remarks, recommendations and limitation of the study.

\section{Review of the Literature}

The well-organized global echelon created by regional integration that aims is facilitating its members to alleviate the adverse effects of globalization and augment the positive impact. The same regional countries reached a treaty to reduce or entirely abolish the tariff and non-tariff restrictions to ensure the free mobility of goods, services, and production factors. Regional integration provides more significant consumer surplus, producer surplus, and economic welfare as a whole. Many regional integrations have originated during the last one decade. The TransPacific Strategic Economic Partnership Agreement (TPP) is one of them that consist of the economies of the Asia-Pacific region.

Many researchers still use customs union theory to assess the trade creation and trade diversion effect of regional integration. Devlin and French-Davis (1998) demonstrated that the severe problem of static analysis of customs union theory is that it uses only partial competitive equilibrium to reach the overall inference about general equilibrium. Besides, Winters (1997) pointed out that trade creation and trade diversion is not the central flaws of testing this model. Still, the primary scarcity of this model is that it does not incorporate empirical foundations and dynamics. Regional integration was constructed using ex-post models that included an importgrowth simulation, gravity model, and other regression methods (Mordechai and Plummer 2002). Due to these features, the Computational General Equilibrium (CGE) model is considered one of the standard tools. It first considers trade and productive growth; second, foreign investment and productivity growth; and finally, endogenous growth and CGE modeling.

Many researchers have been used the CGE model to evaluate the trade gain and welfare impact of 'TPP' mega-regional FTA on different economies. Cororaton and Orden (2015) found that higher investment inflows into the Philippine economy join the TPP agreement to increase welfare gain; otherwise, non-participation decision would create adverse effects on the economy. The majority of the Philippine economy sectors will benefit from the real exchange rate's appreciation due to higher investment inflows from TPP countries. 
Aslan et al. (2015), on the contrary, used the Global Trade Analysis Project (GTAP) database and a Computable General Equilibrium (CGE) model to assess the impact on the Chinese economy under three circumstances. The Chinese economy will deteriorate if only the TTIP is recognized. If China left out when both TTIP and TPP would recognize, the Chinese economy's aggregate damage would be greater than TTIP recognized alone. Only the Chinese economy will positively affect if it decides to join TPP. Therefore, China should decide to join TPP to compensate for the adverse effects of TTIP.

Bryan (2013) pointed out that the TPP's scenarios and possible influence will completely change if Canada, Japan, and Mexico participate in the agreement. Canada and Mexico already have a severe trade relationship with the US because both are NAFTA's trading partners. Japan is considered the third-largest economy globally; the Japanese economy will be larger than aggregate all other negotiating economies except for the US economy. Japan's participation in the TPP agreement triples the agreement's economic value because of its trade and investment with TPP negotiating economies with high tariff and non-tariff restrictions. On the other hand, if it is possible to exclude the US from the agreement and Japan participates in the agreement, at that time, the economic value of the agreement will be double. Therefore, it is evident that their participation will change the outcomes of the TPP agreement.

Ann and John (2011) revealed that the anticipated Trans-Pacific Partnership (TPP) agreement would create a new dimension in the Asia-Pacific region's economic and political perspective. The economies will gain financial benefits from those involved in the initial negotiations of the TPP agreement. The US economy is interested in maintaining prevailing bilateral trade agreement with it collaborates instead of grudging, maintaining the unilateral trade agreement. Moreover, the World Bank, the US International Trade Commission, the Chief Economist's office at Global Affairs Canada, and the Peterson Institute for International Economics have conducted mainstream economic analyses. They found that if the TPP agreement is sanctioned, that will generate net positive economic gains for all negotiating economies. On the other hand, two Tufts University economists have conducted a heterodox economic analysis and suggested that the agreement will create tremendous negative effects on participating economies.

Philip (2013) concluded that developing economies' voices would suffocate if TPP and TTIP created the new trade criterion. Moreover, Rahman and Ara (2016) found that if all tariffs, nontariff, and para tariffs were entirely abolished under these mega agreements, the South Asian economies could suffer from severe negative effects. From this point of view, they suggested that the South Asian economies should join the TPP agreement to compensate for these negative effects.

T. Areerat et al. (2012) used the CEG model. They found that the East Asian economies, including China, Japan, and South Korea, might gain much more real GDP and economic welfare than the TPP agreement because they have existing Free Trade Agreement (FTA) with TPP countries. Besides, Anne-Celia et al. (2015) found that most of the participating economies of TPP and 
developing economies benefited less from these two agreements, while the US agri-food sector would gain more benefit.

Burfisher et al. (2014) conducted a study under a TPP agreement on the region's agriculture in 2025 to assess the possible impacts of removing all agricultural and non-agricultural tariffs and tariff-rate quotas (TRQs). They found that in 2025 under a TRQ and tariff-free, the projected value of intra-regional agricultural trade would be about $\$ 8.5$ billion (in 2007 US dollars) or nearly 6 percent higher from the baseline values. They also estimated that in 2025 due to a TRQ and tarifffree, the US agricultural exports to the region and imports from the region will be $\$ 3$ billion or 5 percent and $\$ 1$ billion or 2 percent, respectively, from the baseline values.

Osman (2016) used the GTAP database to reveal the TPP agreement's impact on Turkey's apparel and textile industries under two distinct scenarios. Firstly, he showed that Turkey's economy would face a GDP loss of 0.037 percent if the negotiating countries of the TPP agreement eliminate all the non-tariffs restrictions on apparel, textile, and fiber-plant products. On the other hand, if the agreement will extend and remove all tariffs and customs that consist of quotas and taxes, the estimated loss of Turkey's GDP will be 0.302 percent. Turkey will also expect a loss in the manufacturing of textiles estimated between 0.30 to 0.77 percent. Turkey's economy expects that the exports (the base year 2009) of apparel and textiles will be declined which is projected as 76.03 to 97.97 and 45.38 to 151.83 million dollars, respectively.

Faruqui et al. (2015) pointed out that, if TTIP and TPP mega deals eliminate tariff and wholly integrated, India and Bangladesh's economy will face a terrific negative impact on their economy. They suggested that if India and Bangladesh joined the TPP agreement, they would minimize these mega deals' negative effects and gain significantly in terms of exports, real GDP, and welfare. Due to these consequences, India and Bangladesh should attempt to join the TPP agreement.

The above analysis points to the fact that the present research endeavor aims to investigate whether Bangladesh will integrate into the TPP agreement or not. A dynamic panel data analysis has applied to the conventional trade model but with new economic integration of the trade balance model that constructed under the gravity model framework on two different scenarios (i.e., TPP without USA and TPP with the USA)

\section{Methodology and Data}

\subsection{Theoretical Model}

Krugman and Baldwin (1987) and Baharumshah (2001) employed the elasticity approach, absorption approach, and monetary approach to construct a trade balance $\left(T B_{i j}\right)$ model that captured the effects of the real exchange rate $\left(R E R_{i j}\right)$, real domestic income $\left(Y_{i}\right)$, and real foreign income $\left(Y_{j}\right)$ on trade. The algebraic form of trade balance $\left(T B_{i j}\right)$ model is: 


$$
T B_{i j}=T B_{i j}\left(Y_{i}, Y_{j}, R E R_{i j}\right)
$$

Tinbergen (1962), Pöyhönen (1963), Deardorff (1997), and Matyas (1997) constructed a gravity model of trade that represented both exports $\left(X_{i j}\right)$ and imports $\left(M_{i j}\right)$ as functions of incomes $Y_{i}\left(Y_{j}\right)$, per capita income $y_{i}\left(y_{j}\right)$, real exchange rate $\left(R E R_{i j}\right)$ in both countries $(i$ and $j)$ and distance $D_{i j}$. Therefore, the algebraic form of trade balance $\left(T B_{i j}\right)$ model is:

$$
T B_{i j}=\frac{X_{i j}^{s}}{M_{i j}^{d}}=T B_{i j}\left(Y_{i}, Y_{j}, y_{i}, y_{j}, R E R_{i j}, D_{i j}\right)
$$

Bahmani-Oskooee (1991, 2001), Anderson, and Wincoop (2003) construed that nominal or real trade balance can determine the country's trade imbalance with its leading trade partners. In the new bilateral trade approach, 'relative size' is far more weighted than 'absolute size' because it determines the export supply and imports demand rather than the income and population of the trading partners. The trade balance $\left(T B_{i j}\right)$ of a country-i with its partner country-j denoted by the ratio of its export over import $\left(X_{i j} / M_{i j}\right)$ suggested by Khan and Hossain (2010). In bilateral trade, the trade balance $\left(T B_{i j}\right)$ is affected by the country-i's GDP compared with the GDP of country-j. In international trade, export and import are determined in terms of f.o.b and c.i.f price, respectively. The transportation cost arises mainly from import. Now, we analyze the impact of the TPP mega deal on the trade balance of Bangladesh. The extended model of trade balance given as follows:

$$
\begin{aligned}
& T B_{i j}=T B_{i j}\left(\frac{Y_{i}}{Y_{j}}, \frac{y_{i}}{y_{j}}, R E R_{i j}, D_{j i}, T A R I F F_{i j}\right) \\
& T B_{i j}=T B_{i j}\left(R G D P_{i j}, R P G N I_{i j}, R E R_{i j}, M W D_{i j}, T A R I F F_{i j}\right)
\end{aligned}
$$

Notations:

$R G D P_{i j}=$ Relative GDP $=\frac{Y_{i}}{Y_{j}}=\frac{G D P_{i}}{G D P_{j}}$

$R P G N I_{i j}=$ Relative per capita income $=\frac{y_{i}}{y_{j}}$

$R E R_{i j}=$ Real exchange rate between country- $\dot{i}$ and country $-j$

$M W D_{i j}=$ Import-weighted distance between country- $\dot{z}$ and country-j

TARIFF $_{i j}=$ Tariff rate of exporter per product HS6 code between country- $\dot{i}$ and 


\subsection{Econometric Model}

This study investigates whether Bangladesh will integrate with the 'TPP' agreement or not. In bilateral trade, the dynamic performance of the trade balance of Bangladesh (country-i) with its trading partners ' TPP' (country-j) can explain by using the following equation (4). The long-run stable relationship between explanatory variables and bilateral trade balance of Bangladesh with its trading partners ' TPP' countries and short-run trade dynamic adjustment can check by using this equation. In this study, several economic variables show the joint dynamic behavior of trade adjustment. Hence, all explanatory variables consist of lagged values of the endogenous variables. The following equation exhibits a dynamic panel model framework:

$$
\begin{aligned}
& \ln \left(T B_{i j}\right)_{t}=\alpha_{0}+\delta \ln \left(T B_{i j}\right)_{t-1}+\beta_{1} \ln \left(R G D P_{i j}\right)_{t}+\beta_{2} \ln \left(R P G N I_{i j}\right)_{t}+\beta_{3}\left(R E R_{i j}\right)_{t} \\
& +\beta_{4} \ln \left(M W D_{i j}\right)_{t}+\beta_{5}\left(T^{\prime} I F F_{i j}\right)_{t}+u_{i j}
\end{aligned}
$$

The above dynamic model constructed in semi-elasticity format to explain the trade balance $\left(T B_{i j}\right)$ in this model incorporated the lagged dependent variable this model we incorporated lagged dependent variable $\left(T B_{i j}\right)_{t-1}, R G D P_{i j}, R P G N I_{i j}$, and $M W D_{j i}$ in natural log (ln) forms whereas $R E R_{i j}$ and $T A R I F F_{i j}$ in absolute form because the real exchange rate and tariff rate showed percentage value for each year. The above model can suffer from endogeneity, autocorrelation, and heteroscedasticity in case of some explanatory variables. In recent times, different estimation techniques have developed to solve these problems in case of dynamic panel model analysis. Some of these techniques have been applied in this research study to investigate the dynamic nature of Bangladesh's trade balance with 'TPP' countries.

The estimators' signs of the variables should be similar to prior expectations according to the theoretical expectations; otherwise, estimated estimators will provide misleading inference. In this above model, the long-run estimator $\beta_{1}$ and $\beta_{2}$ could be either positive or negative. If the home country $-i$ ' $s$ GP is less than the partner country $-j$ 's that will deteriorate the trade balance of the home country and vice versa. On the other hand, if the partner country $-j$ 's per capita GNI ( $R P G N I_{i j}$ ) increase, that will lead to demand for her domestic goods relative to the foreign country $-i$ 's goods and vice versa (absorption effect). According to the J-curve phenomenon the depreciation of real exchange rate $\left(R E R_{i j}\right)$ will increase trade balance after few months of depreciation. Therefore, the expected sign of long-run estimator $\beta_{3}$ will be positive. According to 
the gravity model, import-weighted distance $\left(M W D_{j i}\right)$ is used as a proxy variable of transportation cost. If it increases, that will deteriorate trade balance, and the expected sign of long-run estimator $\beta_{4}$ will be negative. Tariff rate of exporter per product has a positive impact on trade balance.

Therefore, the expected sign of long-run estimator $\beta_{5}$ will be positive. Econometric software Eviews 10 has been used for the purpose of empirical analysis.

\subsection{Data}

we have collected annual data from 2005 to 2020 of different variables from different sources at TPP's country specific for conducting econometric analysis whether Bangladesh will integrate with 'TPP' mega regional trade block or not. To calculate trade balance $\left(T B_{i j}\right)$, we collected exports and imports of goods and services at constant 2010 US\$ from IMF DOTS statistics. To calculate $R G D P_{i j}$ and $R P G N I_{i j}$ we collected Gross Domestic Product (GDP, PPP at constant 2011 international \$ value) and per capita Gross National Income (GNI, PPP at constant 2011 international \$ value) from the World Development Indicator (WDI) database of World Bank. From the International Financial Statistics (IFS) database of the IMF, we collected consumer price index (CPI at constant 2010 value) and official exchange rates (LCU per US\$, period average) for exporting and importing countries to calculate RERs. To calculate import-weighted distance $\left(M W D_{i j}\right)$, we collected the geographical distance of the capital city of Bangladesh to the capital cities of TPP countries from the World Bank website (www.econ.worldbank.org) and then weighted by the ratio of bilateral import volume from corresponding countries to the total import volume of Bangladesh $\left(W_{i j}\right)$. Finally, $T A R I F F_{i j}$ (Tariff rate of exporter per product based on HS6 code) collected from the World Trade Organization (WTO) database. Missing data of various variables fulfilled from various issues of Bangladesh Bank Publications.

\section{Empirical Results}

\subsection{Panel Unit Root Tests}

Before undertaking the long run and short run regression, it is obvious to check whether variables are stationary or not. If variables are non-stationary, then regression will be spurious, and that will provide misleading inference. Different unit root tests are prevalent to check whether variables are stationary or not because a single unit root test sometimes does not provide authentic results. This research work has undertaken a five-unit root test method; these are Levin, Lin and Chu (LLC) test, Breitung t-statistics, Im, Pesaran and Shin W-statistics and ADF-Fisher Chi- square test, and PP - Fisher Chi-square test. We have seen that the equation mentioned earlier (4) variables are non-stationary at level but stationary at first difference. Appendix A1 and A2 represent these summary statistics. 


\subsection{Co-integration Tests}

To draw a concrete decision about cointegration among variables in the model under consideration only single cointegration test may not sufficient (Raihan, 2007). In this research work, we have applied three types of cointegration tests. These are the Pedroni cointegration test, the Kao test, and the combined Johanson Fisher panel cointegration test. Appendix A3 and A4 represent Pedroni, Kao, and Johanson Fisher panel cointegration test statistics respectively. We have seen that except the Pedroni test both Kao and Johanson Fisher panel cointegration test reject null hypothesis of no cointegration. Therefore, we conclude that among the variables of equation (4) exhibits the cointegration relationship.

\subsection{Unrestricted Error Correction Model (UECM)}

From the cointegration test, we have seen that all the variables are cointegrated in the long run. Therefore, the two-step method of Engle and Granger can use by UECM. The following panel regression equations give us the first step Engle and Granger (1987) fixed effect estimators under two different scenarios.

\section{With Integration:}

TPP excludes the USA:

$$
\ln T B_{i j, t}=\alpha_{0 i}+\beta_{1} \ln R G D P_{i j, t}+\beta_{2} \ln R P G N I_{i j, t}+\beta_{3} R E R_{i j, t}+\beta_{4} \ln M W D_{i j, t}+u_{i t}
$$

TPP includes the USA

$$
\ln T B_{i j, t}=\gamma_{0 i}+\delta_{1} \ln R G D P_{i j, t}+\delta_{2} \ln R P G N I_{i j, t}+\delta_{3} R E R_{i j, t}+\delta_{4} \ln M W D_{i j, t}+u_{i t}
$$

\section{Without Integration:}

TPP excludes the USA:

$\ln T B_{i j, t}=\alpha_{0 i}+\beta_{1} \ln R G D P_{i j, t}+\beta_{2} \ln R P G N I_{i j, t}+\beta_{3} R E R_{i j, t}+\beta_{4} \ln M W D_{i j, t}$

$$
+\beta_{5} \text { TARIFF }_{i j, t}+u_{i t}
$$

TPP includes the USA:

$\ln T B_{i j, t}=\gamma_{0 i}+\delta_{1} \ln R G D P_{i j, t}+\delta_{2} \ln R P G N I_{i j, t}+\delta_{3} R E R_{i j, t}+\delta_{4} \ln M W D_{i j, t}$ $+\delta_{5}$ TARIFF $_{i j, t}+u_{i t}$ 
In the second step, the residuals of estimated equations (5), (6), (7), and (8) are stationary; those are tested by using the panel unit root tests and presented in Appendix A6 and A10, respectively.

Table-1: Engle-Granger First Step Estimated Regression Results

\begin{tabular}{|c|c|c|c|c|}
\hline \multicolumn{5}{|c|}{ Dependent Variable: $\ln T B_{i j, t}$} \\
\hline \multirow{2}{*}{$\begin{array}{c}\text { Explanatory } \\
\text { Variable }\end{array}$} & \multicolumn{2}{|c|}{ With Integration } & \multicolumn{2}{|c|}{ Without Integration } \\
\hline & $\begin{array}{l}\text { TPP } \\
\text { excludes } \\
\text { the USA }\end{array}$ & $\begin{array}{c}\text { TPP } \\
\text { includes } \\
\text { the USA }\end{array}$ & $\begin{array}{l}\text { TPP } \\
\text { excludes } \\
\text { the USA }\end{array}$ & $\begin{array}{c}\text { TPP } \\
\text { includes the } \\
\text { USA }\end{array}$ \\
\hline Intercept term & $\begin{array}{c}-0.528 * * * \\
(-3.856)\end{array}$ & $\begin{array}{c}-0.466 * * * \\
(-3.509)\end{array}$ & $\begin{array}{l}-0.944 * * \\
(-2.421)\end{array}$ & $\begin{array}{l}-0.707^{*} \\
(-1.766)\end{array}$ \\
\hline $\ln R G D P_{i j, t}$ & $\begin{array}{c}-11.094 * * * \\
(-6.806)\end{array}$ & $\begin{array}{c}-10.831 * * * \\
(-6.795)\end{array}$ & $\begin{array}{c}-10.410 * * * \\
(-3.137)\end{array}$ & $\begin{array}{l}-8.817 * * \\
(-2.608)\end{array}$ \\
\hline $\ln R P G N I_{i j, t}$ & $\begin{array}{c}9.473 * * * \\
(6.065)\end{array}$ & $\begin{array}{c}9.424 * * * \\
(6.080)\end{array}$ & $\begin{array}{c}9.313 * * \\
(2.879)\end{array}$ & $\begin{array}{l}7.957 * * \\
(2.398)\end{array}$ \\
\hline$R E R_{i j, t}$ & $\begin{array}{c}0.093 * * * \\
(13.946)\end{array}$ & $\begin{array}{c}0.032 * * * \\
(12.327)\end{array}$ & $\begin{array}{c}0.016 * * * \\
(4.030)\end{array}$ & $\begin{array}{l}0.009 * * \\
(2.249)\end{array}$ \\
\hline $\ln M W D_{i j, t}$ & $\begin{array}{l}-1.072 * * * \\
(-23.803)\end{array}$ & $\begin{array}{l}-1.003 * * * \\
(-26.049)\end{array}$ & $\begin{array}{l}-0.926 * * * \\
(-18.863)\end{array}$ & $\begin{array}{c}-0.893 * * * \\
(-18.076)\end{array}$ \\
\hline $\ln T_{A R I F F_{i j, t}}$ & & & $\begin{array}{c}0.218 * * * \\
(13.061)\end{array}$ & $\begin{array}{c}0.213 * * * \\
(13.807)\end{array}$ \\
\hline R-squared & 0.764 & 0.786 & 0.885 & 0.882 \\
\hline Adj. R-squared & 0.757 & 0.780 & 0.879 & 0.876 \\
\hline
\end{tabular}

Notes : 1. Figures in parentheses are $t$ values

2. Asterisk marks $* * *$ and $* * *$ denote the coefficients are significant at $10 \%$, $5 \%$ and $1 \%$ level of significance respectively.

In the panel regression framework, the second-step of Engle-Granger shows error correction estimators in the following ways:

\section{With Integration:}

TPP excludes the USA:

$\Delta \ln T B_{i j, t}=\theta_{i}+\beta_{1} \Delta \ln R G D P_{i j, t-n}+\beta_{2} \Delta \ln R P G N I_{i j, t-n}+\beta_{3} \Delta R E R_{i j, t-n}+\beta_{4} \Delta \ln M W D_{i j, t-n}$

$+\lambda\left[\ln T B_{i j, t}-\alpha_{0 i}-\beta_{1} \ln R G D P_{i j, t-1}-\beta_{2} \ln R P G N I_{i j, t-1}-\beta_{3} R E R_{i j, t-1}\right.$

$\left.-\beta_{4} \ln M W D_{i j, t-1}\right]+u_{i t}$ 
TPP includes the USA:

$\Delta \ln T B_{i j, t}=\phi_{i}+\delta_{1} \Delta \ln R G D P_{i j, t-n}+\delta_{2} \Delta \ln R P G N I_{i j, t-n}+\delta_{3} \Delta R E R_{i j, t-n}+\delta_{4} \Delta \ln M W D_{i j, t-n}$

$+\lambda\left[\ln T B_{i j, t}-\gamma_{0 i}-\delta_{1} \ln R G D P_{i j, t-1}-\delta_{2} \ln R P G N I_{i j, t-1}-\delta_{3} R E R_{i j, t-1}\right.$

$\left.-\delta_{4} \ln M W D_{i j, t-1}\right]+u_{i t}$

\section{Without Integration:}

TPP excludes the USA:

$\Delta \ln T B_{i j, t}=\theta_{i}+\beta_{1} \Delta \ln R G D P_{i j, t-n}+\beta_{2} \Delta \ln R P G N I_{i j, t-n}+\beta_{3} R E R_{i j, t-n}+\beta_{4} \Delta \ln M W D_{i j, t-n}$

$+\beta_{5} \Delta T A R I F F_{i j, t-n}+\lambda\left[\ln T B_{i j, t}-\alpha_{0 i}-\beta_{1} \ln R G D P_{i j, t-1}-\beta_{2} \ln R P G N I_{i j, t-1}\right.$

$+\beta_{3} R E R_{i j, t-1}-\beta_{4} \ln M W D_{i j, t-1}-\beta_{5}$ TARIFF $\left._{i j, t-1}\right]+u_{i t}$

TPP includes the USA:

$\Delta \ln T B_{i j, t}=\phi_{i}+\delta_{1} \Delta \ln R G D P_{i j, t-n}+\delta_{2} \Delta \ln R P G N I_{i j, t-n}+\delta_{3} R E R_{i j, t-n}+\delta_{4} \Delta \ln M W D_{i j, t-n}$

$+\delta_{5} \Delta T A R I F F_{i j, t-n}+\lambda\left[\ln T B_{i j, t}-\gamma_{0 i}-\delta_{1} \ln R G D P_{i j, t-1}-\delta_{2} \ln R P G N I_{i j, t-1}\right.$

$\left.+\delta_{3} R E R_{i j, t-1}-\delta_{4} \ln M W D_{i j, t-1}-\delta_{5} T A R I F F_{i j, t-1}\right]+u_{i t}$

Table-2: Engle-Granger Second Step Estimated Regression Results

\begin{tabular}{|c|c|c|c|c|}
\hline \multicolumn{5}{|c|}{ Dependent Variable: $\Delta \ln T B_{i j, t}$} \\
\hline \multirow{2}{*}{ Explanatory } & \multicolumn{2}{|c|}{ With Integration } & \multicolumn{2}{c|}{ Without Integration } \\
\cline { 2 - 5 } Variable & TPP & TPP & TPP & TPP \\
& $\begin{array}{c}\text { exclude } \\
\text { USA }\end{array}$ & $\begin{array}{c}\text { include } \\
\text { USA }\end{array}$ & $\begin{array}{c}\text { USA } \\
\text { include } \\
\text { USA }\end{array}$ \\
\hline Intercept term & 0.071 & 0.052 & 0.021 & 0.001 \\
(short run) & $(1.045)$ & $(0.749)$ & $(0.338)$ & $(0.012)$ \\
\hline$\Delta \ln R G D P_{i j, t-n}$ & 3.366 & 3.841 & $9.118^{*}$ & $9.674 *$ \\
& $(0.530)$ & $(0.617)$ & $(1.740)$ & $(1.727)$ \\
\hline$\Delta \ln R P G N I_{i j, t-n}$ & -1.782 & -1.953 & $-7.016^{* *}$ & $-7.198^{* *}$ \\
& $(-0.380)$ & $(-0.429)$ & $(-2.225)$ & $(-2.067)$ \\
\hline$\Delta R E R_{i j, t-n}$ & 0.013 & 0.017 & $0.041 * *$ & $0.041^{* *}$ \\
& $(0.897)$ & $(1.225)$ & $(2.219)$ & $(2.271)$ \\
\hline$\Delta \ln M W D_{i j, t-n}$ & $-1.016^{* * *}$ & $-1.003 * * *$ & $-1.039 * * *$ & $-1.014 * * *$ \\
& $(-22.297)$ & $(-22.723)$ & $(-13.517)$ & $(-13.825)$ \\
\hline
\end{tabular}




\begin{tabular}{|c|c|c|c|c|}
\hline$\Delta \ln T A R I F F_{i j, t-n}$ & & & $\begin{array}{c}0.054 \\
(0.995)\end{array}$ & $\begin{array}{c}0.083^{* *} \\
(2.078)\end{array}$ \\
\hline$E C T(\lambda)$ & $-0.31^{* * *}$ & $-0.29^{* * *}$ & $-0.62^{* * *}$ & $-0.55^{* * *}$ \\
& $(-3.599)$ & $(-3.604)$ & $(-3.879)$ & $(-3.649)$ \\
\hline $\ln T B_{i j, t}$ & & & & \\
\hline Intercept term & $-0.528^{* * *}$ & $-0.466^{* * *}$ & $-0.944^{* *}$ & $-0.707^{*}$ \\
(long run) & $(-3.856)$ & $(-3.509)$ & $(-2.412)$ & $(1.766)$ \\
\hline $\ln R G D P_{i j, t-1}$ & $-11.094^{* * *}$ & $-10.831^{* * *}$ & $-10.410^{* * *}$ & $-8.817^{* *}$ \\
& $(-6.806)$ & $(-6.795)$ & $(-3.137)$ & $(-2.608)$ \\
\hline $\ln R P G N I_{i j, t-1}$ & $9.473^{* * *}$ & $9.424^{* * *}$ & $9.313^{* *}$ & $9.957^{* *}$ \\
& $(6.065)$ & $(6.080)$ & $(2.879)$ & $(2.398)$ \\
\hline$R E R_{i j, t-1}$ & $0.039^{* * *}$ & $0.032^{* * *}$ & $0.016^{* * *}$ & $0.009^{* *}$ \\
& $(13.946)$ & $(13.327)$ & $(4.030)$ & $(2.249)$ \\
\hline $\ln M W D_{i j, t-1}$ & $-1.072^{* * * *}$ & $-1.003^{* * *}$ & $-0.962^{* * *}$ & $-0.893^{* * *}$ \\
& $(-23.803)$ & $(26.049)$ & $(-18.863)$ & $(-18.067)$ \\
\hline $\ln T A R I F F_{i j, t-1}$ & & & $0.218^{* * *}$ & $0.213^{* * *}$ \\
& & & $(13.061)$ & $(13.807)$ \\
\hline $\mathrm{R}$-squared (short & 0.627 & 0.621 & 0.728 & 0.711 \\
run) & & & & \\
\hline Adj. R-squared & 0.614 & 0.609 & 0.709 & 0.693 \\
(short run) & & & & \\
\hline
\end{tabular}

Notes: (1). Figures in parentheses are $t$ values

2. Asterisk marks *, ** and $* * *$ denote the coefficients are significant at $10 \%$, $5 \%$ and $1 \%$ level of significance respectively 
Fewer than two separate scenarios (i.e., with integration and without integration), the estimated Unrestricted Error Correction Model (UECM) of equations (9), (10), (11), and (12) have respectively shown the trade balance of Bangladesh with TPP countries in the long run and short run. The t-statistics of each coefficient has shown in parentheses. Therefore, with and without integration, in the long run, the signs of coefficients of explanatory variables (i.e., RGDP, RPGNI, RER, and MWD) are adjusted with priori expectation and statistically significant according to |t2 | rule of thumb under two separate scenarios.

Besides, without the integration of two separate scenarios, the sign of the coefficient of 'TARIFF' is also adjusted with priori expectation and highly significant. However, in the short-run, with and without integration of two separate scenarios, the sign of the coefficient of 'MWD' is adjusted with priori expectation and statistically significant. Therefore, we can conclude that proxy variable import-weighted distance (MWD) has a significant impact on Bangladesh's trade balance, and it indicates that Bangladesh import more from TPP countries rather than export.

\subsection{GMM Estimation}

We have used a one-step and two-step GMM estimation to check whether the proposed model is correctly specified or not. The analysis of one-step and two-step GMM estimation presented in Appendix A8 and A12 have shown that the results of GMM estimators are consistent with unrestricted error correction model (UECM) estimators. Therefore, the proposed model is valid, and no specification biased exists.

\section{Discussion of the Estimated Results}

When all other things remain constant, if the distance between the capital city of Bangladesh and its trading partners of TPP country increased by 1 percent, than bilateral trade balance of Bangladesh (country-i) with its trading partners of TPP country (country-j) decreases by 1.016 , 1.072 and 1.003, 1.003 percent respectively with integration of under both scenarios respectively. On the other hand, 1.039, 0.962, and 1.014, 0.893 percent respectively, without the integration of under both scenarios respectively both in the short-run and long-run. Besides, we have found that 'RPGNI' and 'RER' create a statistically significant impact on Bangladesh trade balance in the short-run without integrating both scenarios. Besides, 'TARIFF' in the short-run without the integration of TPP with the U.S.A also has a significant impact. However, under integration, RGDP has no significant effect in the short run, but it has a statistically significant impact at a 10 percent level of significance without integration.

On the contrary, under both scenarios of with and without integration, the long-run coefficients of relative GDP (RGDP) are statistically significant and are negative $(-11.094,-10.831$ and -10.410 , 
-8.817 respectively). These results have shown that Bangladesh's long-run production and exporting capacity is lower than in TPP countries. Therefore, in the long-run, Bangladesh imports more rather than exports from TPP countries. As a result, in the long-run, the trade balance of Bangladesh deteriorates compared with TPP countries.

Higher relative per capita GNI (RPGNI) indicates a country's higher absorption capacity, which means when a country's relative per capita GNI (RPGNI) increases its import more than export. This study found that the long-run coefficients of relative per capita GNI (RPGNI) are statistically significant and positive $(9.473,9.424$, and 9.313, 9.957, respectively) under both scenarios of with and without integration. Therefore, we draw an inference that TPP countries import more from Bangladesh, and due to this consequence, the trade balance of Bangladesh improves significantly in the long run.

We know that the US dollar acts as a vehicle currency and more than 56 percent of international transactions occur through the US dollar. Therefore, a fluctuation in the exchange rate significantly affects international trade. This study found that coefficients of the real exchange rate (RER) under both scenarios are adjusted with priori expectation and statistically significant and positive in the long-run. However, their values are low (i.e., 0.039, 0.032 and 0.016, 0.009 respectively). The positive sign of this variable's coefficient indicates that when Bangladesh depreciates its currency to TPP countries' currency, then Bangladesh gains a competitive advantage in exports. As a result, the trade balance of Bangladesh improves significantly. Moreover, without the integration of both scenarios, the signs of the long-run coefficients of 'TARIFF' are positive (i.e., 0.218 and 0.213 respectively) and highly significant. Therefore, by providing tariffs to the partners (TPP countries) for exporting per product, foreign currency earnings increase that means capital inflows increase; thus, Bangladesh's trade balance will improve.

The error correction term $\lambda$ 's coefficients of with and without the integration of both scenarios represented as RESID01, RESID03, and RESID02, RESID04, respectively, in Appendix A6 and A10. Those derived from the residuals of long-run equations of (5), (6), (7), and (8), respectively, adjusted with priori expectation, and statistically significant. The error correction term values are less than one in absolute term (i.e., $-0.31,-0.29$ and $-0.62,-0.55$ respectively), showing a valid representation of the error correction mechanism and statistically significant. These coefficients show the adjustment speeds of short-run disequilibrium to the long-run steady-state relationship. Therefore, $0.31 \%, 0.29 \%$, and $0.62 \%, 0.55 \%$ respectively, the disequilibrium errors were corrected within one year under and without integrating both scenarios.

\section{Conclusion}

In this study, we have conducted dynamic panel data analysis to determine whether Bangladesh will integrate with the TPP agreement or not. The panel unit root results, panel cointegration, and two-step GMM test have shown that the proposed model is correct. The UECM model results have shown that with and without the integration of both scenarios (i.e., TPP without USA and TPP 
with the USA), the relative $\operatorname{GDP}\left(R G D P_{i j}\right)$ estimator is statistically significant and negative. It suggests that when TPP countries' relative $\operatorname{GDP}\left(R G D P_{i j}\right)$ increases trade balance of Bangladesh has deteriorated. On the other hand, the relative per capita $\operatorname{GNI}\left(R P G N I_{i j}\right)$ estimator is also statistically significant and positive. It has shown that when TPP countries' absorption capacity increases, they import more from Bangladesh; thus, Bangladesh's trade balance has improved. In our study, we have found that the real exchange rate $\left(R E R_{i j}\right)$ estimator is statistically significant and positive. That tells us that when Bangladesh depreciates its currency compared with TPP countries' currency, its export competitiveness increases, and its trade balance has improved significantly. Moreover, the import weighted distance $\left(M W D_{i j}\right)$ estimator is statistically significant and negative. It indicated that Bangladesh imports most from its neighboring trading partner (i.e., Singapore, Japan, and Malaysia) and exports more distant trading partners (i.e., specifically the U.S.A. and Canada).

Besides, the result of the Tariff rate exporter per product (HS6) without the integration of both scenarios has some positive impacts on the Bangladesh economy with TPP countries through trade balance. This positive impact on the trade balance is that, by providing tariffs to the exporting countries without FTA, the export volume increases; consequently, the export earnings increase, indirectly impacting the trade balance. Moreover, the result of the error correction term $\lambda$ of the UECM suggested that without the integration of both scenarios, the adjustment speeds of shortrun disequilibrium to the long-run equilibrium is required less time rather than with integration of both scenarios.

The results have been mostly consistent across estimation techniques and are expected similar to the dynamic panel data estimation. The estimation of the extended trade balance model with and without the integration of both scenarios has shown that the trade balance of Bangladesh is adversely affected by the relative GDP and import-weighted distance of partner countries. Whereas it positively affected by the relative per capita GNI and the real exchange rate of partner countries, which is both statistically significant. Bangladesh's trade balance is also positively affected by the tariff rate of exporter per product over time. This paper has explored whether Bangladesh should be integrated with TPP mega-regional FTA or not under two different scenarios (i.e., TPP without USA and TPP with the USA) using dynamic panel data analysis techniques the extended trade balance model. The results of UECM have predicted that without the integration of both scenarios, the trade balance of Bangladesh is relatively better off rather than with the integration of both scenarios. As a result, this study concludes that Bangladesh should maintain bilateral trade relationships with TPP countries rather than join the TPP mega-regional FTA.

From the empirical investigation of this study, we can conclude that Bangladesh's trade balance is relatively better off without integration with TPP countries under both scenarios. Therefore, to 
maintain an excellent bilateral trade relationship with TPP countries, the authorities of the Bangladesh government should follow the following recommendations:

- Bangladesh should liberalize its tariff structure because the average tariff of Bangladesh is $55 \%$ that is too high for the country's business's openness.

- The government should liberalize the complicated customs formalities and strictly maintain consumer protection laws in case of imported goods and services.

- The government authority should increase its competency to bargain with its trading partners to reduce the voluntary export restraints (VERs). To achieve this objective government should maintain an excellent bilateral political relationship with its trading partner countries.

- The exporting industries should try to predicate dumping police to drive out its competitors from the global market place and then introduce subsequent monopolistic prices for its products.

- Through the trade policy, the government should increase the share of local content requirements of the final product produced by the local (national) manufacturers to maintain employment.

- The government should impose the countervailing duties on goods subject to countervailing measures when the total amount of subsidy on the imported product of a company to the product's cost is greater than $5 \%$.

- The government should reduce public procurement to avoid the heavy tax burden on taxpayers.

Limitation of the study: The above study measure only the trade creation and trade diversion except for welfare effects. Therefore, further study's scope measures the welfare effects which could be estimated by the GTAP model using the CGE.

\section{Declarations:}

Availability of Data and Materials: We will provide all the pertinent information in future if it is requested by journal authority.

Competing interests: we have no competing interest.

Funding: We do not receive any financial support for any source.

\section{Authors' contributions:}

Nobin Kundu participated in the design of the study and performed the statistical analysis.

Habiba Sultana drafted the manuscript. 
Md. Shaddam Hossain conceived of the study, and participated in its design and coordination and helped to draft the manuscript.

All authors read and approved the final manuscript.

Acknowledgements: We are grateful to Professor M. Zakir Saadullah Khan for his erudite guidelines during conducting this research work.

Ethics approval and consent to participate: Not applicable

Consent for Publication: Not applicable

\section{References}

Anderson and Wincoop (2003). Gravity with Gravitas: A Solution to the Border Puzzle. American Economic Review, 93 (1):170-192.

Ann Capling and John Ravenhill, (2011). Multilateralising regionalism: what role for the TransPacific Partnership Agreement? The Pacific Review, Vol. 24 No. 5 December 2011:553-575

Areerat, T., et al., (2012).Trans Pacific Strategic Economic Partnership with Japan, South Korea and China Integrate: General Equilibrium Approach. American Journal of Economics and Business Administration, 4 (1): 40-46, 2012.

Aslan B. et al. (2015). Transatlantic Trade and Investment Partnership and Trans-Pacific Partnership: Policy Options of China. China \& World Economy/22-43, Vol. 23, No. 6, 2015.

Anne-Celia D.et al. (2015). Atlantic versus Pacific Agreement in Agri-food Sectors: Does the Winner Take it All? G-MonD Working Paper n42. 2015.

Baharumshah, A. Z. (2001). The Effect of Exchange Rate on Bilateral Trade Balance: New Evidence from Malaysia and Thailand, Asian Economic Journal, 15 (3): 291-311.

Bahmani-Oskooee, M. (2001). Nominal and Real Effective Exchange Rates of Middle Eastern Countries and their Trade Performance. Applied Economics, 33: 103-111.

Bhamani-Oskooee, M. (1991). Is There a Long-Run Relation Between the Trade Balance and the Real Effective Exchange Rate of LDCs? Economic Letters, 36: 403-407.

Blundell, R., and S. Bond. (1998). "Initial Conditions and Moment Restrictions in Dynamic Panel Data Models.” Journal of Econometrics, 87(1): 115-143. 
(2000). "GMM Estimation with Persistent Panel Data: An Application to Production Functions”, Econometric Reviews, 19(3): 321-340.

Breitung, Jörg. (2000). “The Local Power of Some Unit Root Tests for Panel Data.” in B. Baltagi (ed.), Nonstationary Panels, Panel Cointegration, and Dynamic Panels Advances in Econometrics, 15, Amsterdam: JAI,pp. 161-178.

Bryan Mercurio, (2013). The Trans-Pacific Partnership: Potential Failure to Game Changer. Australian Institute of International Affairs, No. 14 June 2013: Page 24-25.

Burfisher, et al. (2014). "Agriculture in the Trans-Pacific Partnership." ERR-176, U.S. Department of Agriculture, Economic Research Service, October 2014.

Cororaton B.C. and Orden D. (2015). Potential Economic Effects on the Philippines of the Trans-Pacific Partnership (TPP).GII Working Paper No. 2014-1.

Deardorff, A. (1997). Determinants of Bilateral Trade: Does Gravity Work in a Classical World?The Regionalization of the World Economy, ed. by Jeffrey Frankel. Chicago: University of Chicago Press.

Devlin, Robert, and Ricardo French-Davis, (1998). "Towards an Evaluation of Regional Integration in Latin America in the 1990s.” The World Economy, 22 (2): 261-90.

Faruqui G. A., Ara, L. A. and Qamruzzaman M. (2015). TTIP and TPP: Impact on Bangladesh and India Economy. Pacific Business Review, International Volume 8, Issue 2, August. 2015.

Gujarati, D. (2014). Econometrics by Example. $2^{\text {nd }}$ edition, Palgrave Macmillan

Im, K. S., M. H. Pesaran and Y. Shin. (2003). "Testing for Unit Roots in Heterogeneous Panels." Journal of Econometrics, 115: 53-74.

International Monetary Fund (2016). International Financial Statistics (IFS) CD-ROM 2016. Data from IMF database: www.imfstatistics.org/DOT

Johansen, S. and K. Juselius. (1990). "Maximum Likelihood Estimation and Inference on Cointegration with Applications to the Demand for Money." Oxford Bulletin of Economics and Statistics, 52: 169-210. 
Kao, C. and M. Chiang. (1999). "On the Estimation and Inference of a Cointegrated Regression in Panel Data." Working Paper. Center for Policy Research, Syracuse University, New York.

Khan, M. Zakir Saadullah. and M. Ismail Hossain. 2010. A Model of Bilateral Trade Balance: Extensions and Empirical Tests. Economic Analysis and Policy, 40(3): 377-391

Khan, M. ZakirSaddullah. and M. Ismail Hossain. (2012). "Determinants of Trade Balance of Bangladesh: A Dynamic Panel Data Analysis.” Vol. XXXV, No-2, June.

Krugman, P. R. and R. E. Baldwin (1987). The Persistence of the U.S. Trade Deficit, Brookings Papers on Economic Activity, 1:1-43.

Levin, A., C. F. Lin and S. J. Chu. (2002). "Unit Root Tests in Panel Data: Asymptotic and Finite-Sample Properties." Journal of Econometrics, 108:1-24.

Matyas, Laszlo. (1997). Proper Econometric Specification of the Gravity Model. World Economy 20 (3): 363-368.

Mordechai, K. and Plummer, G. M. (2002). Economic Integration and Development: Has Regional Delivered for Developing Countries? USA: Edward Elgar Publishing Limited, pp. 33-52.

Osman Orkan ÖZER, (2016). The Potential Impact of a Trans-Pacific Partnership (TPP) on the Textile and Appeal Exports of Turkey. TekstilveKonfeksiyon, 26(2), 2016.

Pedroni, P. (1999). "Critical values for cointegration tests in heterogeneous panels with multiple regressors." Oxford Bulletin of Economics and Statistics, special issue, 61: 653-670.

Pedroni, P. (2004). "Panel Cointegration; Asymptotic and Finite Sample Properties of Pooled Time Series Tests with an Application to the PPP Hypothesis." Econometric Theory, 20: 597-625.

Philip I. Levy (2013). Bargains among Behemoths: TPP and TTIP Implications for Developing Countries. This paper was written for the International Trade Department of the World Bank but does not necessarily represent the views of the Bank.

Poyhonen, P. (1963). Toward A General Theory of International Trade, Ekonomiska SamfundetsTidskrift, Tredjeserien, Argang 16: 69-77. 
Rahman M.M. and Ara L.A. (2016). TPP, TTIP and RCEP: Implications for South Asian Economies. South Asia Economic Journal, 16(1) 1-19

Raihan, Selim. (2007). Dynamics of Trade Liberalization in Bangladesh - Analysis of Policies and Practices. Dhaka: Pathak Shamabesh.

Tinbergen, J. (1962). Shaping the World Economy: Suggestions for an International Economic Policy, The Twentieth Century Fund, and New York.

Winters, Alan. (1997). “Assessing Regional Integration Arrangements.” Washington D.C.; U.S: International Trade Division, World Bank (WB)

World Bank (2016). World Development Indicators (WDI) 2016 CD-ROM, World Bank, Washington D.C. Data from World Bank database: www.econ.worldbank.org

World Trade Organization (2016). Tariff rate Exporter per Product HS6 (WTO) CD-ROM 2016. Data from WTO database : https://www.wto.org

\section{Appendices}

Table -A1 : Unit Root Tests Statistics of the Variables of the Model at Level

\begin{tabular}{|c|c|c|c|c|c|c|}
\hline Tests & LN_TB & LN_RGDP & LN_RPGNI & RER & LN_MWD & TARIFF \\
\hline \multicolumn{7}{|c|}{ Levin, Lin \& Chu t* } \\
\hline \multicolumn{7}{|l|}{ TPP } \\
\hline With Intercept & $\begin{array}{c}0.591 \\
(0.723)\end{array}$ & $\begin{array}{c}2.676 \\
(0.996)\end{array}$ & $\begin{array}{c}1.151 \\
(0.875)\end{array}$ & $\begin{array}{c}3.158 \\
(0.999)\end{array}$ & $\begin{array}{c}-1.287 \\
(0.099)\end{array}$ & $\begin{array}{c}0.575 \\
(0.717)\end{array}$ \\
\hline With Intercept \& Trend & $\begin{array}{l}-2.547 \\
(0.145) \\
\end{array}$ & $\begin{array}{l}-3.865 \\
(0.000)\end{array}$ & $\begin{array}{c}-0.994 \\
(0.160) \\
\end{array}$ & $\begin{array}{c}4.994 \\
(1.000) \\
\end{array}$ & $\begin{array}{c}-0.501 \\
(0.308) \\
\end{array}$ & $\begin{array}{l}-2.746 \\
(0.003)\end{array}$ \\
\hline \multicolumn{7}{|l|}{ TPPUSA } \\
\hline With Intercept & $\begin{array}{c}0.522 \\
(0.710) \\
\end{array}$ & $\begin{array}{c}3.023 \\
(0.999) \\
\end{array}$ & $\begin{array}{c}1.345 \\
(0.911) \\
\end{array}$ & $\begin{array}{c}3.333 \\
(1.000) \\
\end{array}$ & $\begin{array}{l}-1.497 \\
(0.067) \\
\end{array}$ & $\begin{array}{c}0.796 \\
(0.787) \\
\end{array}$ \\
\hline With Intercept \& Trend & $\begin{array}{l}-3.044 \\
(0.171) \\
\end{array}$ & $\begin{array}{l}-3.953 \\
(0.000)\end{array}$ & $\begin{array}{c}-0.959 \\
(0.169) \\
\end{array}$ & $\begin{array}{c}4.230 \\
(1.000) \\
\end{array}$ & $\begin{array}{c}-0.571 \\
(0.284) \\
\end{array}$ & $\begin{array}{l}-2.901 \\
(0.002) \\
\end{array}$ \\
\hline \multicolumn{7}{|c|}{ Breitung t-stat } \\
\hline \multicolumn{7}{|c|}{ Ditituig thetat } \\
\hline \multicolumn{7}{|l|}{ With Intercept } \\
\hline With Intercept and Trend & $\begin{array}{c}-0.711 \\
(0.239)\end{array}$ & $\begin{array}{c}2.010 \\
(0.978)\end{array}$ & $\begin{array}{c}-0.891 \\
(0.187)\end{array}$ & $\begin{array}{c}4.912 \\
(1.000)\end{array}$ & $\begin{array}{c}1.429 \\
(0.924)\end{array}$ & $\begin{array}{c}3.113 \\
(0.999)\end{array}$ \\
\hline \multicolumn{7}{|l|}{ TPPUSA } \\
\hline With Intercept & & & & & & \\
\hline
\end{tabular}




\begin{tabular}{|c|c|c|c|c|c|c|}
\hline With Intercept and Trend & $\begin{array}{l}-0.873 \\
(0.191)\end{array}$ & $\begin{array}{c}1.983 \\
(0.976)\end{array}$ & $\begin{array}{l}-0.906 \\
(0.182)\end{array}$ & $\begin{array}{c}4.782 \\
(1.000)\end{array}$ & $\begin{array}{c}1.413 \\
(0.921)\end{array}$ & $\begin{array}{c}3.380 \\
(1.000)\end{array}$ \\
\hline \multicolumn{7}{|c|}{ Im, Pesaran and Shin W-stat } \\
\hline \multicolumn{7}{|l|}{ TPP } \\
\hline With Intercept & $\begin{array}{c}0.859 \\
(0.805)\end{array}$ & $\begin{array}{c}4.645 \\
(1.000)\end{array}$ & $\begin{array}{l}3.467 \\
(1.000)\end{array}$ & $\begin{array}{c}2.474 \\
(0.993)\end{array}$ & $\begin{array}{c}0.217 \\
(0.586)\end{array}$ & $\begin{array}{c}2.250 \\
(0.989)\end{array}$ \\
\hline With Intercept and Trend & $\begin{array}{l}-0.168 \\
(0.433)\end{array}$ & $\begin{array}{l}-0.479 \\
(0.316)\end{array}$ & $\begin{array}{l}0.0796 \\
(0.532)\end{array}$ & $\begin{array}{c}4.872 \\
(1.000)\end{array}$ & $\begin{array}{c}0.721 \\
(0.765)\end{array}$ & $\begin{array}{c}0.705 \\
(0.760)\end{array}$ \\
\hline \multicolumn{7}{|l|}{ TPPusa } \\
\hline With Intercept & $\begin{array}{c}1.092 \\
(0.863) \\
\end{array}$ & $\begin{array}{c}5.231 \\
(1.000)\end{array}$ & $\begin{array}{c}3.882 \\
(1.000)\end{array}$ & $\begin{array}{c}2.895 \\
(0.998) \\
\end{array}$ & $\begin{array}{l}-0.108 \\
(0.457) \\
\end{array}$ & $\begin{array}{c}2.606 \\
(0.995) \\
\end{array}$ \\
\hline With Intercept and Trend & $\begin{array}{r}-0.3899 \\
(0.348) \\
\end{array}$ & $\begin{array}{c}-0.547 \\
(0.292) \\
\end{array}$ & $\begin{array}{c}0.159 \\
(0.563) \\
\end{array}$ & $\begin{array}{c}4.758 \\
(1.000) \\
\end{array}$ & $\begin{array}{c}0.570 \\
(0.716) \\
\end{array}$ & $\begin{array}{c}0.711 \\
(0.762) \\
\end{array}$ \\
\hline \multicolumn{7}{|c|}{ ADF - Fisher Chi-square } \\
\hline \multicolumn{7}{|l|}{ TPP } \\
\hline With Intercept & $\begin{array}{r}14.404 \\
(0.702) \\
\end{array}$ & $\begin{array}{c}19.315 \\
(0.626) \\
\end{array}$ & $\begin{array}{c}7.740 \\
(0.998)\end{array}$ & $\begin{array}{c}9.573 \\
(0.990) \\
\end{array}$ & $\begin{array}{l}12.083 \\
(0.738) \\
\end{array}$ & $\begin{array}{l}17.000 \\
(0.763) \\
\end{array}$ \\
\hline With Intercept and Trend & $\begin{array}{l}17.421 \\
(0.494)\end{array}$ & $\begin{array}{c}26.199 \\
(0.243)\end{array}$ & $\begin{array}{l}18.709 \\
(0.663)\end{array}$ & $\begin{array}{c}2.376 \\
(1.000)\end{array}$ & $\begin{array}{c}11.641 \\
(0.768)\end{array}$ & $\begin{array}{l}17.398 \\
(0.741)\end{array}$ \\
\hline \multicolumn{7}{|l|}{ TPPUSA } \\
\hline With Intercept & $\begin{array}{l}14.559 \\
(0.801) \\
\end{array}$ & $\begin{array}{l}19.324 \\
(0.735) \\
\end{array}$ & $\begin{array}{l}7.791 \\
(0.999)\end{array}$ & $\begin{array}{c}9.630 \\
(0.996)\end{array}$ & $\begin{array}{l}16.042 \\
(0.590)\end{array}$ & $\begin{array}{l}17.072 \\
(0.846)\end{array}$ \\
\hline With Intercept and Trend & $\begin{array}{l}20.704 \\
(0.415) \\
\end{array}$ & $\begin{array}{l}28.382 \\
(0.244) \\
\end{array}$ & $\begin{array}{r}19.682 \\
(0.715) \\
\end{array}$ & $\begin{array}{c}3.418 \\
(1.000) \\
\end{array}$ & $\begin{array}{l}13.898 \\
(0.736) \\
\end{array}$ & $\begin{array}{l}18.672 \\
(0.769) \\
\end{array}$ \\
\hline \multicolumn{7}{|c|}{ PP - Fisher Chi-square } \\
\hline \multicolumn{7}{|l|}{ TPP } \\
\hline With Intercept & $\begin{array}{c}20.388 \\
(0.311)\end{array}$ & 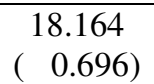 & $\begin{array}{c}10.629 \\
(0.980)\end{array}$ & $\begin{array}{l}11.424 \\
(0.968)\end{array}$ & $\begin{array}{l}12.781 \\
(0.689)\end{array}$ & $\begin{array}{l}19.546 \\
(0.611)\end{array}$ \\
\hline With Intercept and Trend & $\begin{array}{l}26.373 \\
(0.092) \\
\end{array}$ & $\begin{array}{l}62.214 \\
(0.000)\end{array}$ & $\begin{array}{l}19.975 \\
(0.585) \\
\end{array}$ & $\begin{array}{c}2.334 \\
(1.000)\end{array}$ & $\begin{array}{l}11.247 \\
(0.794)\end{array}$ & $\begin{array}{l}22.994 \\
(0.402) \\
\end{array}$ \\
\hline \multicolumn{7}{|l|}{ TPPuSA } \\
\hline With Intercept & $\begin{array}{l}21.821 \\
(0.350) \\
\end{array}$ & $\begin{array}{l}18.185 \\
(0.794) \\
\end{array}$ & $\begin{array}{r}10.696 \\
(0.991) \\
\end{array}$ & $\begin{array}{r}11.430 \\
(0.986) \\
\end{array}$ & $\begin{array}{r}16.586 \\
(0.552) \\
\end{array}$ & $\begin{array}{r}19.550 \\
(0.722) \\
\end{array}$ \\
\hline With Intercept and Trend & $\begin{array}{l}29.229 \\
(0.083) \\
\end{array}$ & $\begin{array}{l}64.230 \\
(0.000) \\
\end{array}$ & $\begin{array}{l}21.112 \\
(0.632) \\
\end{array}$ & $\begin{array}{c}2.873 \\
(1.000) \\
\end{array}$ & $\begin{array}{l}13.034 \\
(0.790) \\
\end{array}$ & $\begin{array}{l}23.737 \\
(0.477) \\
\end{array}$ \\
\hline
\end{tabular}

Note: (a) The null hypothesis states that there is unit root. (b) The critical p-values are reported in parenthesis

Table-A2 : Unit Root Tests Statistics of the Variables of the Model at First Difference

\begin{tabular}{|l|c|c|c|c|c|c|}
\hline Tests & LN_TB & LN_RGDP & LN_RPGNI & RER & LN_MWD & TARIFF \\
\hline \multicolumn{7}{|c|}{ Levin, Lin \& Chu t* } \\
\hline TPP & -9.374 & -6.384 & -6.376 & -3.252 & --5.320 & -5.673 \\
\hline With Intercept & $(0.000)$ & $(0.000)$ & $(0.000)$ & $(0.000)$ & $(0.000)$ & $(0.000)$ \\
\hline With Intercept \& Trend & -8.925 & -6.680 & -5.583 & -4.499 & -8.614 & 9.057 \\
& $(0.000)$ & $(0.000)$ & $(0.000)$ & $(0.000)$ & $(0.000)$ & $(0.000)$ \\
\hline TPPUSA & -10.565 & -6.416 & -6.509 & -4.022 & -6.327 & -6.009 \\
\hline With Intercept & $(0.000)$ & $(0.000)$ & $(0.000)$ & $(0.000)$ & $(0.000)$ & $(0.000)$ \\
\hline
\end{tabular}




\begin{tabular}{|c|c|c|c|c|c|c|}
\hline With Intercept \& Trend & $\begin{array}{l}-10.088 \\
(0.000) \\
\end{array}$ & $\begin{array}{l}-6.581 \\
(0.000)\end{array}$ & $\begin{array}{l}-5.716 \\
(0.000)\end{array}$ & $\begin{array}{l}-5.124 \\
(0.000)\end{array}$ & $\begin{array}{l}-9.506 \\
(0.000)\end{array}$ & $\begin{array}{l}-9.731 \\
(0.000)\end{array}$ \\
\hline \multicolumn{7}{|c|}{ Breitung t-stat } \\
\hline \multicolumn{7}{|l|}{ TPP } \\
\hline \multicolumn{7}{|l|}{ With Intercept } \\
\hline With Intercept and Trend & $\begin{array}{l}-2.482 \\
(0.007)\end{array}$ & $\begin{array}{c}-2.696 \\
(0.004)\end{array}$ & $\begin{array}{c}-2.284 \\
(0.011)\end{array}$ & $\begin{array}{l}-1.880 \\
(0.030)\end{array}$ & $\begin{array}{c}-2.140 \\
(0.016)\end{array}$ & $\begin{array}{c}-0.128 \\
(0.449)\end{array}$ \\
\hline \multicolumn{7}{|l|}{ TPPUSA } \\
\hline \multicolumn{7}{|l|}{ With Intercept } \\
\hline With Intercept and Trend & $\begin{array}{c}-3.002 \\
(0.001) \\
\end{array}$ & $\begin{array}{l}-2.880 \\
(0.002) \\
\end{array}$ & $\begin{array}{c}-2.519 \\
(0.006) \\
\end{array}$ & $\begin{array}{l}-2.246 \\
(0.012) \\
\end{array}$ & $\begin{array}{c}-2.683 \\
(0.004) \\
\end{array}$ & $\begin{array}{c}-0.0702 \\
(0.472) \\
\end{array}$ \\
\hline \multicolumn{7}{|c|}{ Im, Pesaran and Shin W-stat } \\
\hline \multicolumn{7}{|l|}{ TPP } \\
\hline With Intercept & $\begin{array}{l}-6.065 \\
(0.000)\end{array}$ & $\begin{array}{c}-4.135 \\
(0.000)\end{array}$ & $\begin{array}{l}-4.153 \\
(0.000)\end{array}$ & $\begin{array}{c}-1.887 \\
(0.030) \\
\end{array}$ & $\begin{array}{l}-4.614 \\
(0.000)\end{array}$ & $\begin{array}{c}-2.627 \\
(0.004) \\
\end{array}$ \\
\hline With Intercept and Trend & $\begin{array}{l}-3.737 \\
(0.000) \\
\end{array}$ & $\begin{array}{l}3.088 \\
(0.001)\end{array}$ & $\begin{array}{c}-1.328 \\
(0.092)\end{array}$ & $\begin{array}{l}-1.022 \\
(0.014)\end{array}$ & $\begin{array}{c}-3.708 \\
(0.000)\end{array}$ & $\begin{array}{l}-1.332 \\
(0.091)\end{array}$ \\
\hline \multicolumn{7}{|l|}{ TPPUSA } \\
\hline With Intercept & $\begin{array}{l}-6.879 \\
(0.000) \\
\end{array}$ & $\begin{array}{c}-4.139 \\
(0.000) \\
\end{array}$ & $\begin{array}{l}-4.140 \\
(0.000) \\
\end{array}$ & $\begin{array}{c}-2.300 \\
(0.010)\end{array}$ & $\begin{array}{l}-5.471 \\
(0.000) \\
\end{array}$ & $\begin{array}{l}-2.876 \\
(0.002) \\
\end{array}$ \\
\hline With Intercept and Trend & $\begin{array}{l}-4.485 \\
(0.000) \\
\end{array}$ & $\begin{array}{c}-2.892 \\
(0.002)\end{array}$ & $\begin{array}{c}-1.204 \\
(0.014)\end{array}$ & $\begin{array}{l}-1.306 \\
(0.096) \\
\end{array}$ & $\begin{array}{c}-4.515 \\
(0.000)\end{array}$ & $\begin{array}{c}-1.545 \\
(0.061) \\
\end{array}$ \\
\hline \multicolumn{7}{|c|}{ ADF - Fisher Chi-square } \\
\hline \multicolumn{7}{|c|}{ 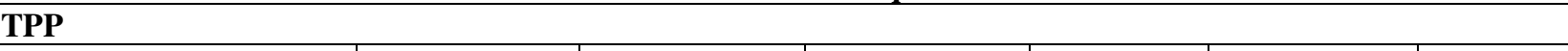 } \\
\hline With Intercept & $\begin{array}{l}71.190 \\
(0.000) \\
\end{array}$ & $\begin{array}{c}56.293 \\
(0.000) \\
\end{array}$ & $\begin{array}{l}55.468 \\
(0.000) \\
\end{array}$ & $\begin{array}{l}33.043 \\
(0.061) \\
\end{array}$ & $\begin{array}{l}54.037 \\
(0.000) \\
\end{array}$ & $\begin{array}{l}46.963 \\
(0.002) \\
\end{array}$ \\
\hline With Intercept and Trend & $\begin{array}{l}55.185 \\
(0.000)\end{array}$ & $\begin{array}{l}44.556 \\
(0.003)\end{array}$ & $\begin{array}{c}28.547 \\
(0.158)\end{array}$ & $\begin{array}{c}26.427 \\
(0.024)\end{array}$ & $\begin{array}{l}53.091 \\
(0.000)\end{array}$ & $\begin{array}{l}42.737 \\
(0.005)\end{array}$ \\
\hline \multicolumn{7}{|l|}{ TPPusa } \\
\hline With Intercept & $\begin{array}{r}83.895 \\
(0.000) \\
\end{array}$ & $\begin{array}{r}59.136 \\
(0.000) \\
\end{array}$ & $\begin{array}{l}58.111 \\
(0.000) \\
\end{array}$ & $\begin{array}{r}39.376 \\
(0.025) \\
\end{array}$ & $\begin{array}{r}66.267 \\
(0.000) \\
\end{array}$ & $\begin{array}{c}52.513 \\
(0.001) \\
\end{array}$ \\
\hline With Intercept and Trend & $\begin{array}{l}65.658 \\
(0.000) \\
\end{array}$ & $\begin{array}{c}45.665 \\
(0.005) \\
\end{array}$ & $\begin{array}{r}29.610 \\
(0.198) \\
\end{array}$ & $\begin{array}{r}30.862 \\
(0.018) \\
\end{array}$ & $\begin{array}{c}64.513 \\
(0.000) \\
\end{array}$ & $\begin{array}{c}49.488 \\
(0.002) \\
\end{array}$ \\
\hline \multirow{2}{*}{\multicolumn{7}{|c|}{ PP - Fisher Chi-square }} \\
\hline \multicolumn{5}{|l|}{ TPP } & & \\
\hline With Intercept & $\begin{array}{l}99.648 \\
(0.000) \\
\end{array}$ & $\begin{array}{l}71.647 \\
(0.000) \\
\end{array}$ & $\begin{array}{l}69.456 \\
(0.000) \\
\end{array}$ & $\begin{array}{c}37.069 \\
(0.023) \\
\end{array}$ & $\begin{array}{l}82.034 \\
(0.000) \\
\end{array}$ & $\begin{array}{l}55.027 \\
(0.000) \\
\end{array}$ \\
\hline With Intercept and Trend & $\begin{array}{l}87.047 \\
(0.000) \\
\end{array}$ & $\begin{array}{l}66.286 \\
(0.000) \\
\end{array}$ & $\begin{array}{l}50.694 \\
(0.001) \\
\end{array}$ & $\begin{array}{l}32.779 \\
(0.065) \\
\end{array}$ & $\begin{array}{l}73.443 \\
(0.000) \\
\end{array}$ & $\begin{array}{l}63.945 \\
(0.000) \\
\end{array}$ \\
\hline \multicolumn{7}{|l|}{ TPPUSA } \\
\hline With Intercept & $\begin{array}{c}118.068 \\
(0.000)\end{array}$ & $\begin{array}{l}74.490 \\
(0.000) \\
\end{array}$ & $\begin{array}{l}71.963 \\
(0.000) \\
\end{array}$ & $\begin{array}{c}43.807 \\
(0.008)\end{array}$ & $\begin{array}{l}94.614 \\
(0.000)\end{array}$ & $\begin{array}{l}60.578 \\
(0.000) \\
\end{array}$ \\
\hline With Intercept and Trend & $\begin{array}{c}107.659 \\
(0.000) \\
\end{array}$ & $\begin{array}{l}67.395 \\
(0.000) \\
\end{array}$ & $\begin{array}{l}51.675 \\
(0.001) \\
\end{array}$ & $\begin{array}{r}42.278 \\
(0.012) \\
\end{array}$ & $\begin{array}{l}88.677 \\
(0.000) \\
\end{array}$ & $\begin{array}{l}78.958 \\
(0.000) \\
\end{array}$ \\
\hline
\end{tabular}

Note: (a) The null hypothesis states that there is unit root. (b) The critical p-values are reported in parenthesis

Table-A3: Cointegration Tests: Pedroni and Kao

\begin{tabular}{|l|l|l|l|l|}
\hline \multirow{2}{*}{ Alternative Hypothesis Tests: AR Coefs. } & \multicolumn{2}{|c|}{ TPP } & \multicolumn{2}{c|}{ TPPusA } \\
\cline { 2 - 5 } & Statistic & $p$-value & Statistic & $p$-value \\
\hline \multicolumn{2}{|c|}{ Pedroni $\boldsymbol{v}$-statistics } & & \\
\hline Within-dimension Statistics & & & & \\
\hline
\end{tabular}




\begin{tabular}{|c|c|c|c|c|}
\hline Without intercept \& trends (None) & -2.551 & 0.995 & -2.672 & 0.996 \\
\hline With intercept \& no trend & -2.513 & 0.994 & -2.652 & 0.996 \\
\hline With both intercept $\&$ trend & -2.907 & 0.998 & -3.101 & 0.999 \\
\hline \multicolumn{5}{|l|}{ Within-dimension Weighted Statistics } \\
\hline Without intercept \& trends & -3.064 & 0.999 & -3.171 & 0.999 \\
\hline With intercept \& no trend & -2.943 & 0.998 & -3.083 & 0.999 \\
\hline With both intercept $\&$ trend & -3.673 & 1.000 & -3.907 & 1.000 \\
\hline \multicolumn{5}{|c|}{ Pedroni $\rho$-statistics } \\
\hline \multicolumn{5}{|l|}{ Within-dimension Statistics } \\
\hline Without intercept \& trends & 2.297 & 0.989 & 2.417 & 0.992 \\
\hline With intercept \& no trend & 3.244 & 0.999 & 3.426 & 1.000 \\
\hline With both intercept \& trend & 3.005 & 0.999 & 3.217 & 0.999 \\
\hline \multicolumn{5}{|l|}{ Within-dimension Weighted Statistics } \\
\hline Without intercept \& trends & 2.450 & 0.999 & 2.604 & 0.995 \\
\hline With intercept \& no trend & 3.089 & 0.999 & 3.319 & 1.000 \\
\hline With both intercept \& trend & 3.237 & 0.999 & 3.580 & 1.000 \\
\hline \multicolumn{5}{|l|}{ Between-dimension Statistics } \\
\hline Without intercept \& trends & 3.872 & 1.000 & 4.154 & 1.000 \\
\hline With intercept $\&$ no trend & 4.580 & 1.000 & 4.900 & 1.000 \\
\hline With both intercept $\&$ trend & 4.263 & 1.000 & 4.683 & 1.000 \\
\hline \multicolumn{5}{|c|}{ Pedroni PP-statistics } \\
\hline \multicolumn{5}{|l|}{ Within-dimension Statistics } \\
\hline Without intercept \& trends & -3.028 & 0.001 & -3.182 & 0.001 \\
\hline With intercept \& no trend & -3.833 & 0.000 & -4.060 & 0.000 \\
\hline With both intercept \& trend & -9.905 & 0.000 & -10.442 & 0.000 \\
\hline \multicolumn{5}{|l|}{ Within-dimension Weighted Statistics } \\
\hline Without intercept \& trends & -2.590 & 0.005 & -2.778 & 0.003 \\
\hline With intercept \& no trend & -7.522 & 0.000 & -7.883 & 0.000 \\
\hline With both intercept \& trend & -12.910 & 0.000 & -13.055 & 0.000 \\
\hline \multicolumn{5}{|l|}{ Between-dimension Statistics } \\
\hline Without intercept \& trends & -6.947 & 0.000 & -7.351 & 0.000 \\
\hline With intercept $\&$ no trend & -8.746 & 0.000 & -9.174 & 0.000 \\
\hline With both intercept $\&$ trend & -17.296 & 0.000 & -17.173 & 0.000 \\
\hline \multicolumn{5}{|c|}{ Pedroni ADF-statistics } \\
\hline \multicolumn{5}{|l|}{ Within-dimension Statistics } \\
\hline Without intercept \& trends & 0.892860 & 0.814 & 0.847 & 0.801 \\
\hline With intercept \& no trend & -0.172672 & 0.432 & -0.353 & 0.362 \\
\hline With both intercept $\&$ trend & NA & NA & NA & NA \\
\hline \multicolumn{5}{|l|}{ Within-dimension Weighted Statistics } \\
\hline Without intercept \& trends & 1.154 & 0.876 & 0.913 & 0.819 \\
\hline With intercept $\&$ no trend & -2.542 & 0.006 & -3.355 & 0.000 \\
\hline With both intercept \& trend & NA & NA & NA & NA \\
\hline \multicolumn{5}{|l|}{ Between-dimension Statistics } \\
\hline Without intercept \& trends & 0.242 & 0.596 & -0.283 & 0.389 \\
\hline With intercept $\&$ no trend & -3.748 & 0.000 & -5.090 & 0.000 \\
\hline With both intercept $\&$ trend & NA & NA & NA & NA \\
\hline \multicolumn{5}{|c|}{ Kao Test } \\
\hline ADF- without trend & -2.893 & 0.002 & -3.158 & 0.002 \\
\hline
\end{tabular}

Table-A4: : Summary of the Johansen Fisher Panel Cointegration Tests 
Series: Series: LN_TB, LN_RGDP, LN_RPGNI, RER, LN_MWD, TARIFF.

Unrestricted Cointegration Rank Test (Trace and Maximum Eigenvalue)

\begin{tabular}{|c|c|c|c|c|}
\hline $\begin{array}{c}\text { Hypothesized } \\
\text { No. of CE(s) }\end{array}$ & $\begin{array}{c}\text { Fisher Stat.* } \\
\text { (from } \lambda_{\text {trace }} \text { test) }\end{array}$ & Prob. & $\begin{array}{c}\text { Fisher Stat.* } \\
\text { (from } \lambda_{\max } \text { test) }\end{array}$ & Prob. \\
\hline \multicolumn{5}{|c|}{ No deterministic trend } \\
\hline \multicolumn{5}{|l|}{ TPP } \\
\hline None & 9.704 & 0.78 & 9.70 & 0.78 \\
\hline At most 1 & 94.88 & 0.00 & 94.88 & 0.00 \\
\hline At most 2 & 157.5 & 0.00 & 110.1 & 0.00 \\
\hline At most 3 & 79.47 & 0.00 & 56.28 & 0.00 \\
\hline At most 4 & 49.62 & 0.00 & 49.62 & 0.00 \\
\hline \multicolumn{5}{|l|}{ TPPUSA } \\
\hline None & 11.09 & 0.80 & 11.09 & 0.80 \\
\hline At most 1 & 113.3 & 0.00 & 113.3 & 0.00 \\
\hline At most 2 & 171.7 & 0.00 & 123.7 & 0.00 \\
\hline At most 3 & 83.02 & 0.00 & 58.30 & 0.00 \\
\hline At most 4 & 54.39 & 0.00 & 54.39 & 0.00 \\
\hline \multicolumn{5}{|c|}{ Linear deterministic trend } \\
\hline \multicolumn{5}{|l|}{ TPP } \\
\hline None & 9.70 & 0.78 & 9.70 & 0.78 \\
\hline At most 1 & 111.9 & 0.00 & 111.9 & 0.00 \\
\hline At most 2 & 128.9 & 0.00 & 128.9 & 0.00 \\
\hline At most 3 & 68.89 & 0.00 & 61.84 & 0.00 \\
\hline At most 4 & 28.99 & 0.01 & 28.99 & 0.01 \\
\hline \multicolumn{5}{|l|}{ TPPUSA } \\
\hline None & 11.09 & 0.80 & 11.09 & 0.80 \\
\hline At most 1 & 113.3 & 0.00 & 113.3 & 0.00 \\
\hline At most 2 & 147.4 & 0.00 & 147.4 & 0.00 \\
\hline At most 3 & 83.86 & 0.00 & 75.30 & 0.00 \\
\hline At most 4 & 34.52 & 0.00 & 34.52 & 0.00 \\
\hline
\end{tabular}

Table-A5: Estimation of the Long-Run Model: With Integration

Method: Panel Least Squares

White cross-section standard errors \& covariance (no d.f. correction)

Dependent Variable: LN_TB(-1)

\begin{tabular}{|c|c|c|c|c|c|c|}
\hline \multirow{3}{*}{ Variable } & \multicolumn{3}{|c|}{ TPP } & \multicolumn{3}{|c|}{ TPPusa } \\
\hline & \multicolumn{3}{|c|}{ Total panel (unbalanced) observations: 154} & \multicolumn{3}{|c|}{ Total panel (unbalanced) observations: 168} \\
\hline & Coefficient & t-Statistic & Prob. & Coefficient & t-Statistic & Prob. \\
\hline LN_RGDP(-1) & -11.094 & -6.804 & 0.000 & -10.831 & -6.795 & 0.000 \\
\hline$\overline{L N \_R P G N I(-1)}$ & 9.473 & 6.065 & 0.000 & 9.424 & 6.080 & 0.000 \\
\hline $\operatorname{RER}(-1)$ & 0.039 & 13.946 & 0.000 & 0.032 & 12.327 & 0.000 \\
\hline LN_MWD(-1) & -1.072 & -23.803 & 0.000 & -1.003 & -26.049 & 0.000 \\
\hline $\mathrm{C}$ & -0.528 & -3.856 & 0.000 & -0.466 & -3.509 & 0.001 \\
\hline \multirow{7}{*}{$\begin{array}{l}\text { Effects } \\
\text { Specification: } \\
\text { Cross-section } \\
\text { fixed (dummy } \\
\text { variables) }\end{array}$} & \multicolumn{2}{|l|}{ R-squared } & 0.764 & \multicolumn{2}{|l|}{ R-squared } & 0.786 \\
\hline & \multicolumn{2}{|c|}{ Adjusted R-squared } & 0.757 & \multicolumn{2}{|c|}{ Adjusted R-squared } & 0.780 \\
\hline & \multicolumn{2}{|c|}{ Akaike info criterion } & 2.756 & \multicolumn{2}{|c|}{ Akaike info criterion } & 2.718 \\
\hline & \multicolumn{2}{|c|}{ Schwarz criterion } & 2.854 & \multicolumn{2}{|c|}{ Schwarz criterion } & 2.811 \\
\hline & \multicolumn{2}{|c|}{ Hannan-Quinn criter. } & 2.796 & \multicolumn{2}{|c|}{ Hannan-Quinn criter. } & 2.756 \\
\hline & \multirow{2}{*}{\multicolumn{2}{|c|}{$\begin{array}{l}\text { Durbin-Watson stat } \\
\text { Log likelihood }\end{array}$}} & 1.813 & \multicolumn{2}{|c|}{ Durbin-Watson stat } & 1.716 \\
\hline & & & -207.180 & \multicolumn{2}{|c|}{ Log likelihood } & -223.330 \\
\hline
\end{tabular}




\begin{tabular}{|l|l|c|l|c|}
\hline & F-statistic & 120.272 & F-statistic & 149.364 \\
\cline { 2 - 4 } & Prob(F-statistic) & 0.000 & Prob(F-statistic) & 0.000 \\
\hline
\end{tabular}

Table-A6: Result of the Residual Unit Root Tests of the Long-Run Model: With Integration

Panel unit root test: Summary

Sample: 2005-2020; Exogenous variables: Individual effects

User-specified lags: 1; Newey-West automatic bandwidth selection and Bartlett kernel

\begin{tabular}{|l|c|c|c|c|c|c|c|c|}
\hline & \multicolumn{5}{|c|}{ TPP } & \multicolumn{3}{c|}{ TPPusa } \\
\hline Method & \multicolumn{3}{|c|}{ Series: RESID01 } & \multicolumn{3}{c|}{ Series: RESID03 } \\
\hline
\end{tabular}

Note: ** Probabilities for Fisher tests computed using an asymptotic Chi-square distribution. All other tests assume asymptotic normality.

Table-A7: Unrestricted Error Correction Mechanism for the Model: With Integration

Method: Panel Least Squares

White cross-section standard errors \& covariance (no d.f. correction)

Dependent Variable: D(LN_TB)

\begin{tabular}{|c|c|c|c|c|c|c|}
\hline \multirow{3}{*}{ Variable } & \multicolumn{3}{|c|}{ TPP } & \multicolumn{3}{|c|}{ TPPUSA } \\
\hline & \multicolumn{3}{|c|}{ Total panel (unbalanced) observations: 148} & \multicolumn{3}{|c|}{$\begin{array}{c}\text { Total panel (unbalanced) observations: } \\
162 \\
\end{array}$} \\
\hline & Coefficient & t-Statistic & Prob. & Coefficient & t-Statistic & Prob. \\
\hline D(LN_RGDP) & 3.366 & 0.530 & 0.597 & 3.841 & 0.617 & 0.538 \\
\hline D(LN_RPGNI) & -1.782 & -0.380 & 0.704 & -1.953 & -0.429 & 0.669 \\
\hline $\mathrm{D}(\mathrm{RER})$ & 0.013 & 0.897 & 0.371 & 0.017 & 1.225 & 0.222 \\
\hline D(LN_MWD) & -1.016 & -22.297 & 0.000 & -1.003 & -22.723 & 0.000 \\
\hline RESID01 & -0.307 & -3.599 & 0.000 & -0.287 & -3.604 & 0.000 \\
\hline $\mathrm{C}$ & 0.071 & 1.045 & 0.298 & 0.052 & 0.749 & 0.455 \\
\hline \multirow{9}{*}{$\begin{array}{l}\text { Effects } \\
\text { Specification: } \\
\text { Cross-section } \\
\text { fixed (dummy } \\
\text { variables) }\end{array}$} & \multicolumn{2}{|c|}{ R-squared } & 0.627 & \multicolumn{2}{|l|}{ R-squared } & 0.621 \\
\hline & \multirow{2}{*}{\multicolumn{2}{|c|}{ Adjusted R-squared }} & 0.614 & \multicolumn{2}{|c|}{ Adjusted R-squared } & 0.609 \\
\hline & & & 1.967 & \multicolumn{2}{|c|}{ Akaike info criterion } & 1.889 \\
\hline & \multicolumn{2}{|c|}{ Schwarz criterion } & 2.088 & \multicolumn{2}{|c|}{ Schwarz criterion } & 2.003 \\
\hline & \multicolumn{2}{|c|}{ Hannan-Quinn criter. } & 2.016 & \multicolumn{2}{|c|}{ Hannan-Quinn criter. } & 1.935 \\
\hline & \multicolumn{2}{|c|}{ Durbin-Watson stat } & 2.446 & \multicolumn{2}{|c|}{ Durbin-Watson stat } & 2.449 \\
\hline & \multicolumn{2}{|c|}{ Log likelihood } & -139.526 & \multicolumn{2}{|c|}{ Log likelihood } & -146.984 \\
\hline & \multirow{2}{*}{\multicolumn{2}{|c|}{$\begin{array}{l}\text { F-statistic } \\
\text { Prob(F-statistic) }\end{array}$}} & 47.775 & F-statistic & & 51.064 \\
\hline & & Prob(F-statistic) & 0.000 & \multicolumn{2}{|c|}{ Prob(F-statistic) } & 0.000 \\
\hline
\end{tabular}


Table-A8: Summary of the GMM Estimations of the Model: With Integration

Dependent Variable LN_TB; Transformation: First Differences

\begin{tabular}{|l|c|c|c|c|}
\hline \multirow{2}{*}{$\begin{array}{l}\text { Explanatory } \\
\text { Variables }\end{array}$} & \multicolumn{2}{|c|}{ TPP } & \multicolumn{2}{c|}{ TPPusa } \\
\cline { 2 - 5 } & $\begin{array}{c}\text { One-Step GMM } \\
\text { Estimators }\end{array}$ & $\begin{array}{c}\text { Two-Step GMM } \\
\text { Estimators }\end{array}$ & $\begin{array}{c}\text { One-Step GMM } \\
\text { Estimators }\end{array}$ & $\begin{array}{c}\text { Two-Step GMM } \\
\text { Estimators }\end{array}$ \\
\hline \multirow{2}{*}{ LN_TB $(-1)$} & $0.094^{* * *}$ & $0.153^{* * *}$ & $0.100^{* *}$ & $0.143^{* *}$ \\
& $(0.03)$ & $(0.01)$ & $(0.02)$ & $(0.03)$ \\
\hline \multirow{2}{*}{ LN_RGDP } & $9.931^{* * *}$ & $11.820^{* * *}$ & $10.112^{* * *}$ & $10.818^{* *}$ \\
& $(0.00)$ & $(0.00)$ & $(0.00)$ & $(0.02)$ \\
\hline \multirow{2}{*}{ LN_RPGNI } & $-6.910^{* *}$ & $-8.664^{* *}$ & $-7.082^{* *}$ & -7.709 \\
& $(0.04)$ & $(0.01)$ & $(0.03)$ & $(0.25)$ \\
\hline RER & $0.038^{* * *}$ & $0.032^{* * *}$ & $0.046^{* * *}$ & $0.050^{* * *}$ \\
\hline \multirow{2}{*}{ LN_MWD } & $(0.00)$ & $(0.00)$ & $(0.00)$ & $(0.00)$ \\
\hline Instrument rank & $-1.132^{* * *}$ & $-1.193^{* * *}$ & $-1.125^{* * *}$ & $-1.202^{* * *}$ \\
$J$-statistics & $(0.00)$ & $(0.00)$ & $(0.00)$ & $(0.00)$ \\
\hline
\end{tabular}

Note: (a) The critical probabilities reported in parentheses.

(b) $* * *$ and $* *$ indicate statistical significance at the $1 \%, 5 \%$ and $10 \%$ level respectively.

(c) The instruments set employed include logarithm of variables in the model dated (t-1) and (t-2). Sargan test statistic is a test of over-identifying restrictions for instrument validity.

Table-A9: Estimation of the Long-Run Model: Without Integration

Method: Panel Least Squares

White cross-section standard errors \& covariance (no d.f. correction)

Dependent Variable: LN_TB(-1)

\begin{tabular}{|c|c|c|c|c|c|c|}
\hline \multirow{3}{*}{ Variable } & \multicolumn{3}{|c|}{ TPP } & \multicolumn{3}{|c|}{ TPPUSA } \\
\hline & \multicolumn{3}{|c|}{ Total panel (unbalanced) observations: 103} & \multicolumn{3}{|c|}{$\begin{array}{c}\text { Total panel (unbalanced) observations: } \\
113\end{array}$} \\
\hline & Coefficient & t-Statistic & Prob. & Coefficient & t-Statistic & Prob. \\
\hline LN_RGDP(-1) & -10.410 & -3.137 & 0.002 & -8.817 & -2.608 & 0.0104 \\
\hline LN_RPGNI(-1) & 9.313 & 2.879 & 0.005 & 7.957 & 2.398 & 0.0182 \\
\hline $\operatorname{RER}(-1)$ & 0.016 & 4.030 & 0.000 & 0.009 & 2.249 & 0.0266 \\
\hline LN_MWD(-1) & -0.962 & -18.863 & 0.000 & -0.893 & -18.076 & 0.0000 \\
\hline TARIFF(-1) & 0.218 & 13.061 & 0.000 & 0.213 & 13.807 & 0.0000 \\
\hline $\mathrm{C}$ & -0.944 & -2.421 & 0.017 & -0.707 & -1.766 & 0.0802 \\
\hline \multirow{9}{*}{$\begin{array}{l}\text { Effects } \\
\text { Specification: } \\
\text { Cross-section } \\
\text { fixed (dummy } \\
\text { variables) }\end{array}$} & \multicolumn{2}{|c|}{ R-squared } & 0.885 & \multicolumn{2}{|l|}{ R-squared } & 0.882 \\
\hline & \multirow{2}{*}{\multicolumn{2}{|c|}{ Adjusted R-squared }} & 0.877 & \multicolumn{2}{|c|}{ Adjusted R-squared } & 0.876 \\
\hline & & & 2.230 & \multicolumn{2}{|c|}{ Akaike info criterion } & 2.271 \\
\hline & \multicolumn{2}{|c|}{ Schwarz criterion } & 2.384 & \multicolumn{2}{|c|}{ Schwarz criterion } & 2.415 \\
\hline & \multicolumn{2}{|c|}{ Hannan-Quinn criter. } & 2.292 & \multicolumn{2}{|c|}{ Hannan-Quinn criter. } & 2.329 \\
\hline & \multicolumn{2}{|c|}{ Durbin-Watson stat } & 1.784 & \multicolumn{2}{|c|}{ Durbin-Watson stat } & 1.826 \\
\hline & \multicolumn{2}{|c|}{ Log likelihood } & -108.863 & \multicolumn{2}{|c|}{ Log likelihood } & -122.290 \\
\hline & \multirow{2}{*}{\multicolumn{2}{|c|}{$\begin{array}{l}\text { F-statistic } \\
\text { Prob(F-statistic) }\end{array}$}} & 148.695 & F-statistic & & 159.957 \\
\hline & & Prob(F-statistic) & 0.000 & \multicolumn{2}{|c|}{ Prob(F-statistic) } & 0.000 \\
\hline
\end{tabular}


Table-A10: Result of the Residual Unit Root Tests of the Long-Run Model: Without Integration

Panel unit root test: Summary

Sample: 2005-2020; Exogenous variables: Individual effects

User-specified lags: 1; Newey-West automatic bandwidth selection and Bartlett kernel

\begin{tabular}{|l|c|c|c|c|c|c|c|c|}
\hline & \multicolumn{5}{|c|}{ TPP } & \multicolumn{3}{c|}{ TPPUsA } \\
\hline & \multicolumn{7}{|c|}{ Series: RESID02 } & \multicolumn{3}{c|}{ Series: RESID04 } \\
\hline Method & Statistic & Prob.** & $\begin{array}{c}\text { Cross- } \\
\text { sections }\end{array}$ & Obs & Statistic & Prob.** & $\begin{array}{c}\text { Cross- } \\
\text { sections }\end{array}$ & Obs \\
\hline Null: Unit root (assumes common unit root process) & & & & & \\
\hline Levin, Lin \& Chu t* & -2.112 & 0.017 & 11 & 91 & -1.593 & 0.056 & 11 & 84 \\
\hline Null: Unit root (assumes individual unit root process) & & & & & \\
\hline $\begin{array}{l}\text { Im, Pesaran and } \\
\text { Shin W-stat }\end{array}$ & 0.192 & 0.076 & 11 & 91 & 0.683 & 0.053 & 11 & 84 \\
\hline $\begin{array}{l}\text { ADF - Fisher Chi- } \\
\text { square }\end{array}$ & 19.316 & 0.026 & 11 & 91 & 19.726 & 0.060 & 11 & 84 \\
\hline $\begin{array}{l}\text { PP - Fisher Chi- } \\
\text { square }\end{array}$ & 23.088 & 0.097 & 11 & 91 & 19.080 & 0.040 & 11 & 95 \\
\hline
\end{tabular}

Note: ** Probabilities for Fisher tests computed using an asymptotic Chi-square distribution. All other tests assume asymptotic normality.

Table-A11: Unrestricted Error Correction Mechanism for the Model: Without Integration

Method: Panel Least Squares

White cross-section standard errors \& covariance (no d.f. correction)

Dependent Variable: D(LN_TB)

\begin{tabular}{|c|c|c|c|c|c|c|}
\hline \multirow{3}{*}{ Variable } & \multicolumn{3}{|c|}{ TPP } & \multicolumn{3}{|c|}{$\begin{array}{c}\text { TPP USA } \\
\end{array}$} \\
\hline & \multicolumn{3}{|c|}{ Total panel (unbalanced) observations: 91} & \multicolumn{3}{|c|}{ Total panel (unbalanced) observations: 100} \\
\hline & Coefficient & t-Statistic & Prob. & Coefficient & t-Statistic & Prob. \\
\hline D(LN_RGDP) & 9.118 & 1.740 & 0.085 & 9.674 & 1.727 & 0.088 \\
\hline D(LN_RPGNI) & -7.016 & -2.226 & 0.029 & -7.198 & -2.076 & 0.041 \\
\hline D(RER) & 0.041 & 2.219 & 0.029 & 0.041 & 2.271 & 0.026 \\
\hline D(LN_MWD) & -1.039 & -13.517 & 0.000 & -1.014 & -13.825 & 0.000 \\
\hline D(TARIFF) & 0.054 & 0.995 & 0.322 & 0.083 & 2.078 & 0.040 \\
\hline RESID02 & -0.621 & -3.879 & 0.000 & -0.550 & -3.649 & 0.000 \\
\hline $\mathrm{C}$ & 0.021 & 0.338 & 0.736 & 0.001 & 0.012 & 0.991 \\
\hline \multirow{9}{*}{$\begin{array}{l}\text { Effects } \\
\text { Specification: } \\
\text { Cross-section } \\
\text { fixed (dummy } \\
\text { variables) }\end{array}$} & \multicolumn{2}{|c|}{ R-squared } & 0.728 & \multicolumn{2}{|l|}{ R-squared } & 0.711 \\
\hline & \multicolumn{2}{|c|}{ Adjusted R-squared } & 0.709 & \multicolumn{2}{|c|}{ Adjusted R-squared } & 0.693 \\
\hline & \multicolumn{2}{|c|}{ Akaike info criterion } & 1.886 & \multicolumn{2}{|c|}{ Akaike info criterion } & 1.842 \\
\hline & \multicolumn{2}{|c|}{ Schwarz criterion } & 2.079 & \multicolumn{2}{|c|}{ Schwarz criterion } & 2.024 \\
\hline & \multicolumn{2}{|c|}{ Hannan-Quinn criter. } & 1.964 & \multicolumn{2}{|c|}{ Hannan-Quinn criter. } & 1.916 \\
\hline & \multicolumn{2}{|c|}{ Durbin-Watson stat } & 2.436 & \multicolumn{2}{|c|}{ Durbin-Watson stat } & 2.513 \\
\hline & \multicolumn{2}{|c|}{ Log likelihood } & -78.806 & \multicolumn{2}{|c|}{ Log likelihood } & -85.100 \\
\hline & \multirow{2}{*}{\multicolumn{2}{|c|}{$\begin{array}{l}\text { F-statistic } \\
\text { Prob(F-statistic) }\end{array}$}} & 37.540 & \multicolumn{2}{|c|}{ F-statistic } & 38.188 \\
\hline & & Prob(F-statistic) & 0.000 & \multicolumn{2}{|c|}{ Prob(F-statistic) } & 0.000 \\
\hline
\end{tabular}


Table-A12: Summary of the GMM Estimations of the Model: Without Integration

Dependent Variable LN_TB; Transformation: First Differences

\begin{tabular}{|l|c|c|c|c|}
\hline & \multicolumn{2}{|c|}{ TPP } & \multicolumn{2}{c|}{ TPP USA } \\
\hline Explanatory & $\begin{array}{c}\text { One-Step GMM } \\
\text { Estimators }\end{array}$ & $\begin{array}{c}\text { Two-Step GMM } \\
\text { Estimators }\end{array}$ & $\begin{array}{c}\text { One-Step GMM } \\
\text { Estimators }\end{array}$ & $\begin{array}{c}\text { Two-Step GMM } \\
\text { Estimators }\end{array}$ \\
\hline$\Delta$ LN_TB (-1) & $0.019^{* *}$ & $0.003^{*}$ & $0.020^{*}$ & $-0.003^{*}$ \\
& $(0.03)$ & $(0.08)$ & $(0.06)$ & $(0.07)$ \\
\hline \multirow{2}{*}{ LN_RGDP } & $6.721^{*}$ & $10.756^{* *}$ & $7.153^{* *}$ & $14.518^{* *}$ \\
& $(0.06)$ & $(0.02)$ & $(0.03)$ & $(0.01)$ \\
\hline \multirow{2}{*}{ LN_RPGNI } & $-4.536^{* *}$ & $-6.683^{* *}$ & -4.743 & $-11.181^{* *}$ \\
& $(0.01)$ & $(0.04)$ & $(0.09)^{*}$ & $(0.04)$ \\
\hline \multirow{2}{*}{ RER } & $0.046^{*}$ & $0.077^{* *}$ & $0.044^{* *}$ & $0.018^{* * *}$ \\
& $(0.08)$ & $(0.03)$ & $(0.06)$ & $(0.04)$ \\
\hline \multirow{2}{*}{ LN_MWD } & $-1.100^{* * *}$ & $-1.057^{* * *}$ & $-1.097^{* * *}$ & $-1.130^{* * *}$ \\
& $(0.00)$ & $(0.00)$ & $(0.00)$ & $(0.00)$ \\
\hline \multirow{2}{*}{$\Delta$ TARIFF } & $0.150^{* *}$ & $-0.289^{* *}$ & $0.13^{* * *}$ & $0.172^{* *}$ \\
\hline Instrument rank & $(0.00)$ & $(0.01)$ & $(0.00)$ & $(0.05)$ \\
$J$-statistics & 76 & 11 & 77 & 12 \\
\hline
\end{tabular}

Note: (a) The critical probabilities reported in parentheses.

(b) $* * *$ and $* *$ indicate statistical significance at the $1 \%, 5 \%$ and $10 \%$ level respectively.

(c) The instruments set employed include logarithm of variables in the model dated (t-1) and (t-2). Sargan test statistic is a test of over-identifying restrictions for instrument validity. 